\title{
BETWEEN FREEDOM AND RECLUSION: SOCIAL SUPPORT AS A QUALITY-OF-LIFE COMPONENT IN THE FAMILY CAREGIVER-DEPENDENT PERSON BINOMIAL ${ }^{1}$
}

\author{
Silvia Cristina Mangini Bocchi ${ }^{2}$ \\ Margareth Angelo ${ }^{3}$
}

Bocchi SCM, Angelo M. Between freedom and reclusion: social support as a quality-of-life component in the family caregiver-dependent person binomial. Rev Latino-am Enfermagem 2008 janeiro-fevereiro; 16(1):15-23.

This is a qualitative study which uses Grounded Theory as its methodological framework and Symbolic Interactionism as a theoretical base to understand the experience of family caregivers for Cerebrovascular Accident (CVA) patients with regard to social support during their rehabilitation process at home. The components (themes and categories) of the phenomenon assuming home care and specifically the themes assuming care with support and assuming care without support were inter-related for the purpose of comparison and analysis, in order to apprehend how the interaction between them occurred. It was observed that, in addition to the recovery of the patient's autonomy, social support is one of the intervenient components in the quality of life for the family caregiverdisabled person binomial, particularly with respect to the caregiver's freedom to resume his/her life plan.

DESCRIPTORS: social support; cerebrovascular accident; patients; family; rehabilitation

\section{ENTRE LA LIBERTAD Y LA RECLUSIÓN: EL APOYO SOCIAL COMO UN COMPONENTE DE LA CALIDAD DE VIDA DEL BINOMIO CUIDADOR FAMILIAR Y PERSONA DEPENDIENTE}

Se trata de un estudio cualitativo que utiliza como referencial metodológico la Grounded Theory y como referencial teórico el Interaccionismo Simbólico para comprender la experiencia de cuidadores familiares de personas con ACV y su relación con el apoyo social que reciben durante el proceso de rehabilitación de persona con ACV en el domicilio. Interrelacionando los componentes (temas y categorías) relativos al fenómeno del cuidado en el domicilio y específicamente a los temas: asumir el cuidado con apoyo y asumir el cuidado sin apoyo, procuramos compararlos y analizarlos para aprehender cómo se daba la interacción entre ellos. Percibimos que, además de la recuperación de la autonomía del enfermo, el apoyo social es una de las variables intervinientes en la calidad de vida del binomio cuidador familiar-persona dependiente y está específicamente relacionada a la libertad del cuidador de retomar su plan de vida.

DESCRIPTORES: apoyo social; accidente cerebrovascular; pacientes; familia; rehabilitación

\section{ENTRE A LIBERDADE E A RECLUSÃO: O APOIO SOCIAL COMO COMPONENTE DA QUALIDADE DE VIDA DO BINÔMIO CUIDADOR FAMILIAR-PESSOA DEPENDENTE}

Trata-se de um estudo qualitativo, utilizando-se como referencial metodológico a Grounded Theory e como referencial teórico o Interacionismo Simbólico, para compreender a experiência de cuidadores familiares de pessoas com AVC, acerca do apoio social, durante o processo de reabilitação de pessoa com AVC no domicílio. Ao interrelacionar os componentes (temas e categorias) relativos ao fenômeno assumindo o cuidado no domicílio e especificamente aos temas: assumindo o cuidado com suporte e assumindo o cuidado sem suporte, buscando compará-los e analisá-los para apreender como se dava à interação entre eles. Percebemos que, além da recuperação da autonomia do doente, o apoio social é uma das variáveis intervenientes na qualidade de vida do binômio cuidador familiar-pessoa dependente e, especificamente, relacionada à liberdade do cuidador retomar o seu plano de vida.

DESCRITORES: apoio social; acidente cerebrovascular; pacientes; família; reabilitação

${ }^{1}$ Research supported by the Brazilian Scientific and Technological Development Council (CNPq), process: $142247 / 96-0 ;{ }^{2}$ RN, PhD, Assistant Professor at Botucatu Medical School, São Paulo State University, Brazil, e-mail: sbocchi@fmb.unesp.br; ${ }^{3}$ RN, PhD, Full Professor, School of Nursing, University of São Paulo, Brazil, e-mail: angelm@usp.br 


\section{INTRODUCTION}

Since 1996, Cerebrovascular Accidents (CVA) have been the leading cause of hospitalization, mortality and disability affecting over-50-year-old individuals in the Brazilian population, presently surpassing heart disease and cancer $^{(1)}$.

Since the 1940s, Brazil has experienced an inversion process in mortality curves and a decline in the number of deaths resulting from infectious diseases with a concomitant increase in deaths due to nontransmittable chronic degenerative diseases and external causes. This process is known as the epidemiological transition phenomenon and has occurred in all presently developed countries, where the elderly population is increasingly more expressive ${ }^{(1)}$.

It is estimated that, in Brazilian hospitals, approximately $10 \%$ of hospitalizations since 1996 have been due to diseases in the circulatory system, which have been responsible for $17.2 \%$ of costs $^{(1)}$.

Even when not lethal, such diseases frequently lead to partial or total disability with serious outcomes to the patient, his family and society. This shows that the investment in the prevention of such diseases is decisive not only to ensure quality of life to disabled individuals and his relatives, but also to prevent hospitalization expenses that have become increasingly costly due to the high level of sophistication of modern medicine ${ }^{(1)}$.

Although physical diseases may take a variety of forms, it is within the family sphere that they will be increasingly more often resolved; therefore, professionals need to be instrumentalized in order to develop a critical view for quality care provision.

Various authors reinforce the vital role played by the family in determining the outcomes of patient rehabilitation ${ }^{(2)}$. Authors add that an individual's severe physical disability gives rise to a crisis not only for the family, but also for the individual himself. Disability is a condition that requires long periods of supervision, observation and care. Due to long-term needs, the disabled person often depends on his relatives for physical care, social contact, psychological support and financial help. The recovery level may depend on the family's ability to provide support to the disabled person, which frequently becomes a significant burden to the family ${ }^{(3-4)}$.

These are the reasons that have motivated investigatory processes on the experience of family caregivers for CVA aiming at expanding knowledge on the subject as a feedback strategy for teaching, research and care.

The purpose of this paper was to understand the experience of a sample of family caregivers as regards the social support received during home care rehabilitation of CVA patients.

\section{SOCIAL SUPPORT CONCEPT}

Despite the large number of studies and results associating social support with health and disease levels, the social support concept presents definition and operationalization problems.

Therefore, we consider it opportune to carry out an analysis on the origin of the term, the ways it has been defined and the forms in which recent investigation has dealt with the association of social support availability with well-being and health.

The most frequently used terms are: social support and social networks, but is common to find terms such as social relationships, social integration, social ties and social anchorage being indistinctively used $^{(5)}$. Nevertheless, most indicators agree that social support would be composed of a structure and a function, which are distinct aspects and phenomena and that, as such, must be evaluated and examined.

The structure of social relationships refers to the organization of ties among people and can be described under different aspects, such as the number of social relationships maintained or roles played by an individual, frequency of contacts with various members of a network, density, multiplicity and reciprocity of relationships among the members of a network, among others. The structure of social relationships consists of the network of formal and informal relationships. Formal relationships are those maintained as a result of positions and roles played in society and include professionals such as: physicians, dentists, teachers, lawyers, etc, among others. Informal social relationships - those considered to be more personally and affectively important than other specialized and formal relationships - consist of all individuals (family, friends, neighbors, colleagues, community) and ties among individuals with whom a close family relations or affective involvement is kept. Measuring the structure of the social network allows for evaluating the level 
in which an individual is socially connected with others, his level of social isolation or integration ${ }^{(5)}$.

The function of social support includes the level of resources provided by others and can be specified in four aspects:

1. mental support, which involves expressions of love and affection;

2. instrumental support, which refers to "concrete" help, provision to material needs in general, help with practical work (house cleaning, meal preparation, provision of transportation) and financial help;

3. informational support, which concerns information (advice, suggestions, guidance) that can be used to deal with problems and their resolution;

4. positive social interaction, which includes the availability of people with whom it is possible to enjoy oneself and relax.

It has not yet been well clarified how the structural and functional aspects of social support are inter-related. Some authors point out that the number and structure of individuals' ties may be less important for the perception of support received than having at least one tie that is rather close or trustworthy. However, others state that network structure is crucial to facilitate access to various types of functional care. Additionally, it has been shown that the extent of a person's social network, network cohesion and the types of relationships in such network (strong or weak ties) are factors that influence the receipt of various sorts of social support ${ }^{(6)}$.

Since the first investigations concerning the influence of social relationships on health were carried out in the 1970s and 1980s, knowledge and understanding as regards the substance and complexity of social support has advanced, and the literature associating social support with mental health has gained shape. Some researchers have concluded that social support is a multidimensional social construct, describing different of social support types or categories that must be taken into account and that can have different effects on individuals' physical and mental health ${ }^{(7)}$.

\section{METHODOLOGICAL PATHWAY}

This study is a part of a broader investigation on the experience of family caregivers for CVA patients which resulted in a theoretical model denominated: moving between freedom and reclusion: going through an experience of little joy when becoming a family caregiver for a CVA patient ${ }^{(8)}$.

As the investigation's final report was extensive and, since this subject has not been widely approached according to the theoretical and methodological perspective adopted at times when CVA has constituted the major cause of hospitalizations, mortality and disability leading health care professionals to seek for guiding frameworks to provide family care, communicating knowledge by means of various articles is justified. In this article, the phenomenon assuming home care is presented as concerns the social support dimension, which consists of two themes: counting on support and not counting on support.

This is a qualitative study conducted according to ethical precepts which involved family caregivers located from records obtained at the Medical Information Center (CIMED) of a University Hospital and through the Physical Therapy Service of a General Hospital in São Paulo State, Brazil.

Family members identifying themselves as family caregivers were regarded as actors, since they had assumed the major non-remunerated responsibility for a disabled individual's home care.

The interviews were conducted in the caregivers' own homes by taking into account their availability so that they could confidentially answer the following guiding question to the researcher: what has your experience of giving care to a CVA patient been like?

When the taping of each interview was concluded, the interview was transcribed and analyzed according to the phases of the methodological framework based on the Grounded Theory: discovering categories, connecting categories, developing memos and identifying the $\operatorname{process}^{(9)}$.

Categories, according to the authors, are abstractions of the phenomenon observed in the data, and they form the main analysis unit of the Grounded Theory. The theory is developed through the work conducted with the categories, which leads to the emergence of the core category as a result of the analysis, which is usually a process ${ }^{(9)}$.

Theoretical saturation was obtained after the analysis of the $10^{\text {th }}$ interview. Of the 10 family caregivers, nine were females and one was a male, which resulted from the difficulty in finding males playing such role. Their ages varied from 36 to 69 years, and they had been acting as caregivers from 
three months to five years. Relationship level was distributed among six spouses, two daughters, one mother-in-law and one stepmother. Their family income ranged from one to 20 minimum salaries.

A point was made of returning to the caregivers' homes in order to present the theoretical model, which was submitted to evaluation by the actors and validated as representative of their experiences.

The results were discussed in the light of Symbolic Interactionism according to Charon ${ }^{(10)}$.

\section{PRESENTING THE EXPERIENCE}

The experience of family caregivers for CVA patients as regards the social support dimension is unfolded into two themes: assuming care with support and assuming care without support.

A - Assuming care with support

This is the first theme composing the phenomenon assuming home care. It includes categories revealing the experience of the family caregiver who feels supported in the care giving process, particularly when he can count on a companion for the patient, which enables him to experience pleasure in the practice of his freedom and autonomy through activities and roles (re)assumed out of his home. This theme is composed of three categories.

\section{A1 - Counting on support}

When assuming care, the family caregiver may count on help that supports him in the process of caring for the patient, thus relieving burden, as compared to the experience of not counting on any type of support. This category joins all types of support encountered in the experience of a family caregiver for CVA patients, denominated as: having good financial conditions, counting on health insurance, counting on the help of a maid, counting on home nursing, being helped by the family and being supported by the community.

... I thank God for being able to count on some money savings today so that I can take good care of my husband. He himself provided this condition ...So, I thank God. I always make sure he has what he needs...
... we have been able to share the housework. My granddaughter and I take M. to the bathroom and to the shower. My granddaughter is also responsible for doing the laundry and cleaning the house, and M.'s son cooks...

... luckily I can count on the transportation provided by the local government to take my mother to physical therapy three times a week....

... we have to resort to everything. I even counted on prayers by evangelicals who used to come here to my house. Everything has helped ...

A2 - Feeling supported

The family caregiver feels assisted in coping with the challenges posed by the role assumed when he can count on support. This feeling is awoke when: providing the patient with all the necessary treatment and well-being, being successful in family agreements, being visited, finding people to talk to, perceiving that one's prayers are answered by God and going to church.

... I think that it must be very sad not to have resources to care for a sick person. I have good enough conditions to take good care of my husband whereas many people don't. This is very sad...

... my daughters and my sons-in-law have helped me. They are very good to me. Our family is very attached. Whenever I need it, I call, and we can always manage to arrange schedules, even though they have a job...

... what has helped me is going to church and praying for God to give me strength and patience to continue taking care of my husband ...

A3 - Not feeling imprisoned when assuming the caregiver role

When the family caregiver can count on the help of a companion for the patient, he leaves his domestic life which previously offered no socioeconomic autonomy and assumes the activities that were performed by the patient, thus allowing himself not to feel imprisoned when playing the caregiver's role. This experience is lived when: abandoning a life of patient's dependence, counting on companionship for the patient and assuming other roles that allow him to go out.

... Do you know how I've assumed all this? ... Ever since I was a child, I had wanted to do it. While people want to go to college, travel and go to school, this was my choice. I wanted to have a family. I wanted to have children. I wanted to have a 
home. I wanted to take care of all this. Then, it happened to me... Then, what happened? ... Why would I try to do it if there was someone to do it for me? So, I never had to worry about anything. He always did everything for me. Why should I be concerned? ... ... we know that when a problem like this knocks at our door, it's our problem and not someone else's. We have to assume it ... I need to go out, because life goes on ... I have to go to the bank ... I have to cash my pension. I can't leave it to somebody else to do it. I have to do it. I have to manage things, because everything goes on ...

B - Assuming care without support

This is the second theme composing the phenomenon assuming home care. It gathers categories around the challenges faced by the family caregiver when playing his role in unfavorable conditions to count on support during the care giving process.

This experience triggers feelings of abandonment as well insecurity in leaving the patient , particularly when it is not possible to provide him with companionship due to complicating conditions such as unfavorable financial conditions or the caregiver's or his relatives' beliefs. This leads him to evaluate the course of events and perceive that this experience is circumscribed by suffering, which promotes disorganization of the family function and affects physical and mental health.

By evaluating the effects in his life, he begins to plan and operate strategies to get rid of an unpleasant role. This theme congregates the following categories.

B1 - Not counting on support

This is an experience that aggregates the subcategories related to difficulties leading the family caregiver for CVA patients to experience the performance of a role without counting on help. This experience joins the following situations: having financial difficulties, coping with the patient's resistance to hiring a caregiver, having difficulty in finding the ideal caregiver, facing difficulty in obtaining care giving collaboration from the family, preserving children's lives from problems, not trusting the care offered by the family, being resistant to asking the family for help and facing the family's resistance to hiring a caregiver.

... My husband had a good income working as an electrician, and now it's over ...I also used to sew a lot, and that helped with the family budget, but I've had to stop taking care of him and because of my spinal cord and leg problems...

... My mother doesn't accept people from out of the family taking care of her. I have found several people, but she sends them away by gesturing. It's very hard in this way ...

... My sister doesn't understand. She keeps saying that she is afraid to hire a person from out of the family to look after our mother because they may beat her. Then, I say that we have to hire someone we know, ask for references for this person...

...finding a person like this, someone responsible to look after a sick person like her. She can't talk. So, it's hard to find someone like this, someone responsible to look after a sick person like her ... Besides being very expensive, it's hard. Not everyone likes to look after sick people...

... nobody helps me. They can't ... you see! One was unemployed, only now has he started working again. The other daughters work ... I can't give them more problems ... They are beginning their lives now ...

B2 - Feeling forsaken

This is a feeling that is awakened in the family caregiver when he realizes the difficulties resulting from the fact of not counting with support during the performance of their role as: having difficulty to obtain treatment for the patient, having to cope with the house's physical barriers, facing difficulties to look after the patient by oneself, family members staying away from the patient and from the family caregiver, feeling lonely without having anyone to share problems, feeling pressured to get rid of the caregiver role, feeling deceived by one's own family and feeling punished by God.

... If we could give a little more comfort, but we can't. You see the problem to have physical therapy. We couldn't get it through the Unified Health System (SUS). I had to pay for a package to have it done. Only now is it beginning to be done by SUS ... It's hard to get it. You have to spend the night standing in line to get it ... There are places for only 10 patients. I was lucky. I was the ninth ...

... The difficult thing is the bathroom, which is outside the house, and then he has to wash in the backyard because the wheel chair will not go through the bathroom door ...

... I'm not strong enough to turn him and lift him. I always need another person to help me ... but my son is never home...

...I'm thankful to you because I have unburdened my heart to you. I was keeping all this to myself and feeling oppressed. We can never find anyone to listen to us. Who can you talk to? People talk about other things. They set you aside. It's our problem and it'll always be the same. No one listens to you... 
... my husband even told me: it's either she or I. If not, I'll find an apartment and move out of here because I can't stand your mother anymore ...

B3 - Feeling insecure about leaving the patient

This feeling emerges as a result of a set of variables that awaken fear and insecurity in the family caregiver when he leaves the patient by himself which are present in the experiences: learning the risks of CVA recurrence, losing a partner and having to leave the patient.

... my sister invited me to spend Christmas in her house, but as my mother doesn't want to go, so I can't go either. If she went, I would go too, but as she isn't going, I'll stay here...

... now I have to hurry even to go to the supermarket because I'm afraid ... to leave him ... He may have a CVA again at any time, as the doctor said. Like the first time it happened. He fell to the floor, urinated on himself, he fell in the middle of the night. He fell off the bed, and I didn't even notice. So, I'm afraid. So, I hurry to supermarket, but my mind stays here ...

B4 - Feeling imprisoned by taking the caregiver role

This is a consequence of the fact that the family caregiver feels insecure about going away from the patient, which makes him feel recluse to the activities related to the patient and the house, by means of the following experiences: having to abandon an independent life and assuming activities that make him feel imprisoned.

... you have to give yourself up to everything else. I don't participate in anything anymore. I don't even participate in the church activities or in the elderly group's activities anymore. I've quit doing gym. I have virtually given myself up. I only live for my mother and my husband here at home, and don't do anything else...

... I have to be promptly available. I can't go out because if I do, she may suddenly need to go to the bathroom ...I have to be here whenever she needs me.

B5 - Viewing family life as compromised

This is the perception that the family caregiver has in relation to the disorganization of his own family when experiencing the role of a family caregiver in the condition of not being given support. This perception emerges when: perceiving that one is disturbing the family, seeing arguments among family members, having marital problems and feeling financially wronged by one's own family.

... So, there are certain things that make feel like a burden to another person who also has a family to take care of. So, it's a chain of problems ... he's an architect. So, let's suppose he has a client. He needs to cancel that client's appointment because it's time to take his father to the doctor's. Then you know that you are disturbing. There's no need to mention it. How many times has he come late! My husband gets angry and says: why didn't you call to say that you couldn't make it. I would've called a cab. My son says: ah! Father, I'm sorry. I was with a client. I can't just tell clients to go away. So, you realize that, although you don't mean to do it, you are disturbing someone else's life ...

... At the beginning, when my father got sick, ... I argued with my husband and he left. We were separated for almost a year. Then, he came back. Then, he decided to separate again because I was too nervous. He even said that he could understand me, but couldn't take that situation anymore ... It's difficult! You see. I had my house, my life there. My husband and I. Then, we left there and moved here, thinking that things would be a certain way, and now that we are here, he has to be everyone's father ... he's playing a role that shouldn't be his. My husband is a very good man, but who can take all this? ...

B6 - Living with suffering

It means that, in playing his role, the family caregiver experiences a process of suffering associated with that of the patient himself, which, in its turn leads him to recall his own previous sorrows as well as to turn to the others surrounding the family members. It's experienced in situations as: sharing the patient's feelings, recalling the suffering from previous losses when experiencing the present one and having other current family problems that add to suffering.

... he's improving with physical therapy, but since he can't control his right side, you know what it's like. He's very nervous, becomes resentful and cries, and I end up crying to and also become resentful ...

... I have very bad memories. I suffered a lot when I was fifteen years old. I took care of my father who'd had a stroke, and then my mother got blind due to glaucoma, and now my husband ...

B7 - Perceiving that health is being lost

It means that in the family caregiver's experience without support, he is susceptible to developing physical and mental health problems, and 
individuals with a previous chronic disease may present related complications as well develop new ones. This perception emerges when: developing health problems and aggravating health conditions.

... I get nervous ... for no reason. Anything makes me nervous and irritated. You see! I've gotten fat. I've gained $17 \mathrm{Kg}$ and now I have high blood pressure ... See! I had my own house, my life there...

... we used to travel, go fishing, and all of sudden, everything is over. Now, I invite him to visit relatives or to a wedding, but he won't go ...so, we stay here stuck at home... everything is over and we feel imprisoned ... That's why I've become depressed ...

... I've head leg problems and had to have catheterization.

This is serious. Can you imagine? I've developed spinal cord and leg problems ... and I'm hypertensive ...

\section{B8 - Trying to change the situation}

It means that the family caregiver uses strategies to get rid of his role and resume his life plan, and when he realizes that this is not possible, he positions himself in consideration to the patient. This experience consists of strategies as: trying to overcome the difficulties in hiring a caregiver, forcing the search for another caregiver and proposing to continue giving care to the patient.

... I have tried, but I haven't been able to find the way to change ... The problem is that my mother will not accept outsiders to take care of her. So, this is difficult. I'm trying to organize it with this lady to see if I can get my mother to adapt to her so that I can have some more free time to give attention to my husband ...

... We had always been good friends, and we had always gotten along well. Then, when this problem came up... She already had another child. Then, when she left hospital, she went there. There, they didn't get along. She told me that her daughter-in-law kept fighting with her son because of her. Then, one day, she went back to her other son's house. Then, sometimes I would go there, and she was alone. The other day, I went there and found her crying and complaining that she was left alone. I ended up staying with her for two days. Then, I decided to take her to my house because it would be easier for me to do the housework and take care of her and of my little grandchild ...

...my mother used to take care of me, and now I see my mother in this situation. It's very hard. So, I'm going to take care of her until her final day. It's not easy, and it's necessary to be very patient ...

\section{ANALYZING AND DISCUSSING THE EXPERIENCE}

When inter-relating the components (themes and categories) relative to the phenomenon assuming home care and specifically the themes: assuming care with support and assuming care without support with the purpose of comparing and analyzing them in order to understand how they interacted, it was noticed that, in addition to the recovery of the patient's autonomy, social support is one of the intervenient components in the family caregiver's quality of life and in the patient's rehabilitation process.

When analyzing the movement of the categories belonging to the family member's experience assuming home care for CVA patients, it was observed that categories counting on support and not counting on support composed the social support dimension, which was responsible for changing the direction of the experience, and, consequently served as a element of the actors' quality of life.

The experience not counting on support depicts the family caregiver perceiving that his health is being lost due to the dissatisfaction resulting from a recluse life that is full of suffering and void of perspectives of resuming his life plan, particularly when the process of autonomy recovery of both the person victimized by CVA and his are interdependent and conditioned to the level of rehabilitation achieved by the patient.

On the other hand, the family caregiver's health preservation is observed in the experiences in which he feels supported and in favorable conditions to proceed with his life plan in face of his established freedom, contrarily to what happens during the experience of those who cannot count on support and who, when feeling confined to the caregiver's role and in face of the insecurity of leaving the patient, begins to face many personal losses, such as: seeing family life as compromised, living with suffering and, consequently, perceiving that his health is being lost.

Therefore, in the situations where the caregiver cannot envision the patient's autonomy recovery, social support is revealed as the second determinant contributing to the caregiver's physical and mental health preservation, protecting him from the resulting exposures to feelings of abandonment and reclusion imposed by the role.

The moving between freedom and reclusion theoretical model shows that when the family caregiver 
realizes that his possibilities of freeing himself from the role, either through actions aiming at recovery or in counting on a companion for the patient, are exhausted, he may take one of two directions: accommodating to the care giving situation or resuming the strategies that can free $\operatorname{him}^{(8)}$.

To that theoretical model, accommodating to the situation means that the family caregiver decides to continue playing his role with the patient. Despite the burden that the patient may pose to his life, the caregiver tries to overcome or manage the problems with resignation in consideration for the patient.

On the other hand, it adds that the family caregiver's actions may move towards becoming free of the role and searching for another caregiver by means of two strategies: trying to overcome hiring difficulties and forcing the search for another person.

To the theoretical model, trying to overcome the difficulties in hiring a caretaker means that the family caregiver resumes his previously abandoned strategies in order to solve the problems related to hiring a new person so that the latter can integrally assume the patient's care. Additionally, he may use another strategy, that is, the search for another caregiver; however, this could cause a state of suffering to the patient due to attitudes of disregard towards him, who may then externalize his feelings. With that, he achieves his goal of making visible to other members of the household that the patient may be better cared for by another person and, sensitized by the situation, they would take measures to find another caregiver $^{(8)}$.

These actions can be explained by Symbolic Interactionism, according to Charon(10), when considering that actions are caused by the subject's active decision-making process that involves the definition of the situation, which, in its turn, involves, interaction with oneself and with others. Thus, the definition of the situation, made by the actor, is central to how the action will occur.

Therefore, the health care team must evaluate the experience of the family caregiverdisabled person binomial in order to understand how the caregiver defines his role. If he defines it as not counting on support and, consequently, feeling imprisoned by the role, interventions must be directed to searching social support as a strategy to preserve the caregiver's health and the patient's rehabilitation process.
This study corroborates previously conducted epidemiological studies, showing social support as a predictor for health ${ }^{(11)}$; morbidities, such as cardiovascular disease ${ }^{(12)}$; incidence of heart ischemic disease $^{(13)}$ and mortality ${ }^{(14)}$. Additionally, other studies show the beneficial effects of social support networks on the survival of patients with breast cancer ${ }^{(15)}$, cancer in general and $\mathrm{CVA}^{(12)}$ while this study enhances understanding by signaling that the social support strategies that preserve caregiver's health and the disabled person's rehabilitation process are those which cause the caregiver to feel free to resume his plan, previously abandoned in order to take his role.

\section{MAKING FINAL CONSIDERATIONS}

This study has made it possible to understand that, in addition to the patient's autonomy recovery, social support is one of the intervenient components in the quality of life of the family caregiver-disabled person binomial as it provides freedom for the family caregiver to resume his life plan. For that purpose, the background presented will help health care professionals to apprehend how the family caregiver perceives social support. In case, he manifests feelings of reclusion to the role played in face of lack of support, interventions must be directed to seeking social support as a strategy for preserving the caregiver's health and the patient's rehabilitation process.

This background can also serve as teaching content for families of disabled individuals so as to convince them as regards the need to gather help.

These are the reasons why the accesses by the family caregiver-disabled person binomial to Public Health Care Policies that continuously promote programs for evaluation and implemented interventions by health care teams become essential. It is a role that burdens those giving care to patients who do not present promising conditions for autonomy recovery, particularly if they are unprovided with affective social support. We point out that they are likely to have their physical and mental health exposed to the effects of assuming the family caregiver's role, which may even compromise the patient's rehabilitation/re-adaptation process and lead them to undertake extreme actions by submitting the patient to mistreatment. 


\section{REFERENCES}

1. Ministério da Saúde [homepage na Internet]. Brasília: Ministério da Saúde; [Acesso em 2004 maio 06]. Programas e projetos: doenças cardiovasculares; [3 telas]. Disponível em: http://www.saude.gov.br.

2. Reeber BJ. Evaluating the effects of a family education intervention. Reabil Nurs 1992 November-December; $17(6): 332-6$

3. Youngblood NM, Hines J. The influence of the family's perception of disability on rehabilitation outcomes. Reabil Nurs 1992 November-December; 17(6):323-6.

4. Ski C, O'Connell B. Stroke: The increasing complexity of carer needs. J Neurosci Nurs 2007 June; 39(3):172-9.

5. Due P, Holstein B, Lund R, Modvig J, Avlund K. Social relations: Network, support and relational strain. Soc Sci Med 1999 March; 48(5):661-73

6. Thoits PA. Stress, coping, and social support processes: Where are we? What next? J Health Soc Behav 1995; Special: 53-79.

7. Turner RJ, Marino F. Social support and social structure: A descriptive epidemiology. J Health Soc Behav 1994 September; 35(3):193-212.

8. Bocchi SCM. Movendo-se entre a liberdade e a reclusão: Vivendo uma experiência de poucos prazeres ao vir-a-ser um cuidador familiar de uma pessoa com AVC. [Tese]. São Paulo (SP): Escola de Enfermagem/USP; 2001.

9. Glaser BG, Strauss A L. The discovery of grounded theory. Hawthorne (NY): Aldine; 1967.

10. Charon JM Symbolic interactionism: an introduction, an interpretation, an integration. Englewood Cliffs (NJ): Prentice Hall; 1989.

11. Litwin H. Social network type and morale in old age. Gerontologist 2001 August; 41(4):516-24.

12. Kawachi I, Colditz GA, Ascherio A, Rimm EB, Giovannucci E, Stampfer MJ, et al. A prospective study of social networks in relation to total mortality and cardiovascular disease in men in the USA. J Epidemiol Community Health 1996 June; $50(3): 245-51$.

13. Vogt TM, Mullooly JP, Ernst D, Pope CR, Hollis JF. Social networks as predictors of ischemic heart disease, cancer, stroke and hypertension: Incidence, survival and mortality. J Clin Epidemiol 1992 June; 45(6):659-66.

14. Ceria CD, Masaki KH, Rodriguez BL, Chen R, Yano K, Curb JD. The relationship of psychosocial factors to total mortality among older Japanese-American men: The Honolulu Heart Program. J Am Geriatr Soc 2001 June; 49(6):725-31.

15. Wallsten SM, Tweed DL, Blazer DG, George LK 1999. Disability and depressive symptoms in the elderly: The effects of instrumental support and its subjective appraisal. Int J Aging Hum Dev 1999; 48(2):145-59. 